\title{
Rевевсн Автіске: Estimation of avoidable yield losses against Sesamia inferens in promising maize hybrid with endosulfan spraying
}

\author{
V. SAILAJA, K. VIJAYA LAKSHMI AND K. LOKA REDDY
}

Article Chronicle: Received : 14.08.2017;

Revised : 09.09.2017; Accepted : 26.09.2017

\section{KEY Words:}

Sesamia inferens, Maize, Avoidable yield loss

Author for correspondence :

\section{SAILAJA}

Department of

Entomology, College of Agriculture, Professor

Jayashankar Telangana

State Agricultural

University,

Rajendranagar, HYDERABAD

(TELANGANA) INDIA

Email:sailajavallabuni@ gmail.com

See end of the article for authors' affiliations
SUMMARY : Artificial infestation of Sesamia inferens larvae at 2 leaf stage (7 DAE) of the crop growth (Table 1) recorded significantly lowest mean grain yield of $47.59 \mathrm{q} \mathrm{ha}^{-1}$ than infested at $4\left(53.44 \mathrm{q} \mathrm{ha}^{-1}\right)$, $6\left(59.84 \mathrm{q} \mathrm{ha}^{-1}\right)$ and $8\left(67.34 \mathrm{q} \mathrm{ha}^{-1}\right)$ leaf stage of the crop. Artificial infestation of the maize crop with different larval densities $(0,5,10,15$ and 20 larvae per plant) (Table 2) indicated that release of 20 larvae per plant adversely affected the grain yield and recorded $49.97 \mathrm{q} \mathrm{ha}^{-1}$ which was significantly less than the grain yield obtained with 15 larval density $\left(54.12 \mathrm{q} \mathrm{ha}^{-1}\right)$ and 10 larval density per plant $(57.32 \mathrm{q} \mathrm{ha}$ ${ }^{1}$ ). Estimation of avoidable yield losses in maize crop against $S$. inferens (Table 3 ) indicated that among the different stages of the crop growth, 2 leaf stage of the crop protected with endosulfan recorded maximum avoidable yield loss with different larval densities $(18.17 \%, 22.45 \%, 35.12 \%, 37.62 \%$ and $45.39 \%$ with $0,5,10,15$ and 20 larval density per plant, respectively), than the other stages of crop and hence spraying of endosulfan at early stages of crop growth was found highly effective for controlling $S$. inferens and for obtaining higher yields.

How to cite this article : Sailaja, V., Lakshmi, K. Vijaya and Reddy, K. Loka (2017). Estimation of avoidable yield losses against Sesamia inferens in promising maize hybrid with endosulfan spraying. Agric. Update, 12(4): 610-614; DOI : 10.15740/HAS/AU/12.4/610-614. 